\title{
A gênesis, Shila Joaquim
}

\author{
The genesis, Shila Joaquim \\ La génesis, Shila Joaquim
}

Shila Joaquim ${ }^{1}$

\footnotetext{
1 Shila Joaquim, artista visual residente em São Mateus - ES. Licenciada em Educação do Campo e Ciências Naturais, Mestranda no Programa de PósGraduação em Ensino na Educação Básica na Universidade Federal do Espírito Santo (UFES) |

Lattes: http://lattes.cnpq.br/2598521277328825

E-mail: shilajoaquim@gmail.com
} 


\title{
Resumo
}

O ensaio trata do processo criativo de Shila Joaquim onde destaca a Poesia como principal elemento da estrutura de seu modo de criar e fazer arte. Do lugar de artista autodidata relaciona o não saber à liberdade de criação, neste percurso acessa memórias e delineia caminhos percorridos na produção de algumas obras citadas.

\section{Palavras-chave}

Poesia, processo criativo, desenho, pintura.

\begin{abstract}
The essay deals with Shila Joaquim's creative process where she highlights Poetry as the main element of the structure of her way of creating and making art. From the place of a self-taught artist he relates not knowing to the freedom of creation, in this path he accesses memories and delineates paths taken in the production of some of the aforementioned works.
\end{abstract}

\section{Keywords}

Poetry, creative process, drawing, painting.

\section{Resumen}

El ensayo aborda el proceso creativo de Shila Joaquim donde destaca la poesía como el elemento principal de la estructura de su forma de crear y hacer arte. Desde el lugar de un artista autodidacta relaciona el desconocimiento con la libertad de creación, en este camino accede a los recuerdos y delinea caminos tomados en la producción de algunas de las obras mencionadas.

\section{Palabras clave}

Poesía, proceso creativo, dibujo, pintura. 


\section{O início foi dado pela poesia}

A Poesia foi a primeira linguagem a me afetar. Através das metáforas que conheci criança, e que ficavam guardadas à chave num móvel de meu pai, leitor cafuzo, entendi as relações entre o que parecia distinto. As metáforas rompiam o meu isolamento, o isolamento das coisas, e possibilitavam a construção de ideias que se faziam figuras (sempre humanas!), mas que se nascessem palavras não dariam conta de construir os sentidos que eu só compreenderia depois, mas que naquele momento eram necessários apenas como expressão.

A partir do encontro com as metáforas compreendi que, entre uma "coisa|elemento|figura|sentimento", existia um mundo de relações, ideias, associações, analogias, possíveis conversas.

Por isso concluo que a poesia, através das metáforas, plantou em mim um pensamento sistêmico que repercute no desenho, na pintura, na dramaturgia e na minha maneira de ver, sentir e traduzir o mundo.

No começo, desenhava rosto de pessoas. Eram rostos com histórias, sentimentos e narrativas que só eu sabia. O desenho evoluía e se amparava pelos palpites de meu pai que, entre uma escultura e outra, me dava goles de aprovação. Eu sorvia, em meio às minhas lutas com os riscos de narizes e bocas. Nessa peleja, a figura humana se enraizou como principal elemento do meu texto imagético. A paisagem não existia, e quando surgiu, era um elemento que explicava a figura. Somente depois, nesse agora, passou a ser uma relação da figura com a Vida, e com todo restante dos elementos existentes no espaço branco. A complexidade emocional, centrada antes na figura, evoluiu para a complexidade do que é tecido junto.

A relação com a cor se construiu na vida adulta, penso que estava adormecida. Hoje a entendo como herança de minha mãe, costureira e bordadeira, de gosto colorido.

Entre o desenhar e o pintar, houve uma lacuna de mais de trinta anos. Um dia perguntei à Raquel Trindade se ela poderia me ensinar a pintar e ela respondeu:

- Não, não sei ensinar, só sei dizer se é bom... E arrematou dizendo que, se eu soubesse desenhar, saberia pintar. Muito tempo depois fui ver que Ingres disse a mesma coisa de maneira diferente.

Então, foi a linha e a ignorância que orientaram minha pintura. A linha como elemento estruturante. As curvas sempre foram preferidas - os ângulos e as quebras desses encontros pouco me interessaram. O volume, muito procurado, achei na compreensão de que os pêlos do pincel eram inúmeras linhas, que davam forma através da carga de tinta. Era só obedecer o sentido das linhas... As linhas vistas e as imaginárias. As visíveis davam sentido, organizavam a figura, e as imaginárias davam volume.

A ignorância deu-me a certeza que o não saber implicava em exercício de liberdade. Nunca pesou, em mim, o desejo de provar algo, e nem ter determinado resultado. Os trabalhos eram aceitos como passos do percurso, eram resultados de conversas internas, um aconchego! Podia fazer o que eu quisesse, porque eu não 
sabia, então... Estava tudo bem. A tela era um espaço de criação, sem regras, a ser ocupado pelos meus desejos, e assim se transformou no meu espaço de pensamento.

A cor não me serve de orientação, a cor é sempre uma experiência nova, não tenho receita, meu modus operandi com a cor vem dos pensamentos produzidos pela figura que desejo representar, as figuras e seu entorno inspiram-me cores, essas ou aquelas.

\section{A temática}

Os pensamentos quadro, inicialmente, diziam respeito às culturas populares e ao que eu acreditava ser sagrado - aos Bois, aos Catopês, às Folias de Reis, à Boa Morte, aos Orixás... Que, com o seu colorido, apresentavam um todo de texturas, uma padronagem. Naquela beleza, o que me interessava era inventar a narrativa das individualidades daqueles brincantes e suas relações uns com os outros. A pintura retratava o namoro da jongueira com o marujo de Reis, a presença caótica do bêbado, a moça solitária em meio da multidão, o ambulante que aproveita a aglomeração para vender seu produto, o triste vendedor de pássaros. Miudezas do cotidiano, as pequenas coisas de que a vida é formada. Tudo ao mesmo tempo, também interessava a simultaneidade e a vivência do teatro, nesse sentido, me ajudava a organizar as cenas e criar as relações.

Nutri vontade secreta de ser boa colorista como Luzia Caetano, e que minhas figuras inspirassem movimento, como as figuras de Raquel Trindade.

Então tinha a linha curva, o tema, o colorido, a simultaneidade. Queria conseguir a sobreposição. A sobreposição das coisas no mundo que, como a pintura, era visto por mim, feito de camadas. Planos que, muitas vezes, meu repertório de linhas não dava conta de organizar no espaço da tela. Quando isso acontecia era assombrada por buracos. Espaços vazios. Espaço sem relação.

O Casamento da Pastorinha, 80x60, acrílica sobre tela, me conduziu pela primeira vez à Bienal Naifs do Brasil. Na época, havia assistido uma apresentação olímpica de ginástica rítmica onde os jurados analisavam os exercícios obrigatórios que a coreografia da ginasta tinha que demonstrar com habilidade. Peguei a ideia como referência para pensar a tela. 


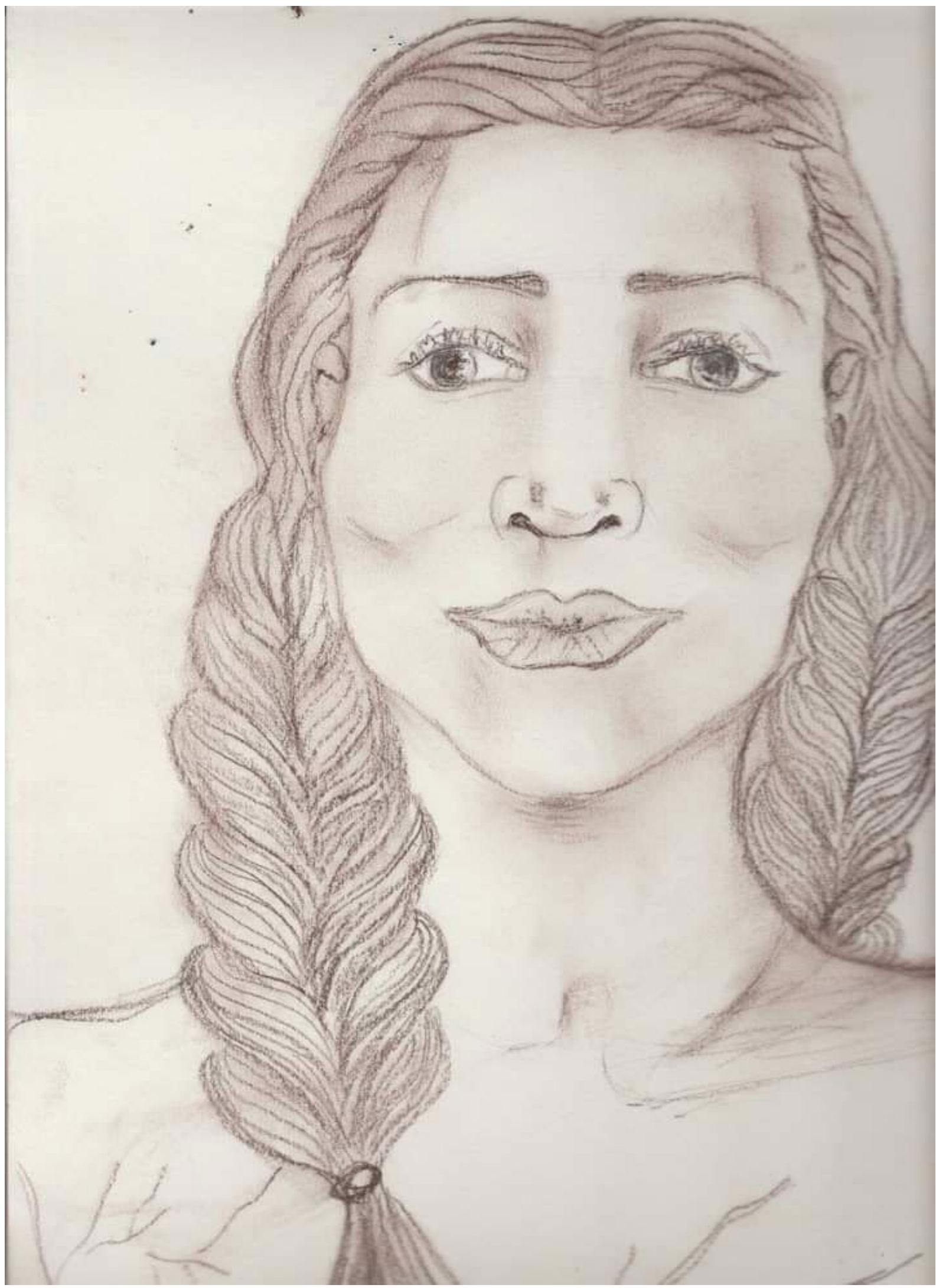

Fig. 01, Estudo para rosto da obra O casamento da pastorinha, 2016, grafite sobre papel, 29,7x 21 $\mathrm{cm}$, coleção da artista. 


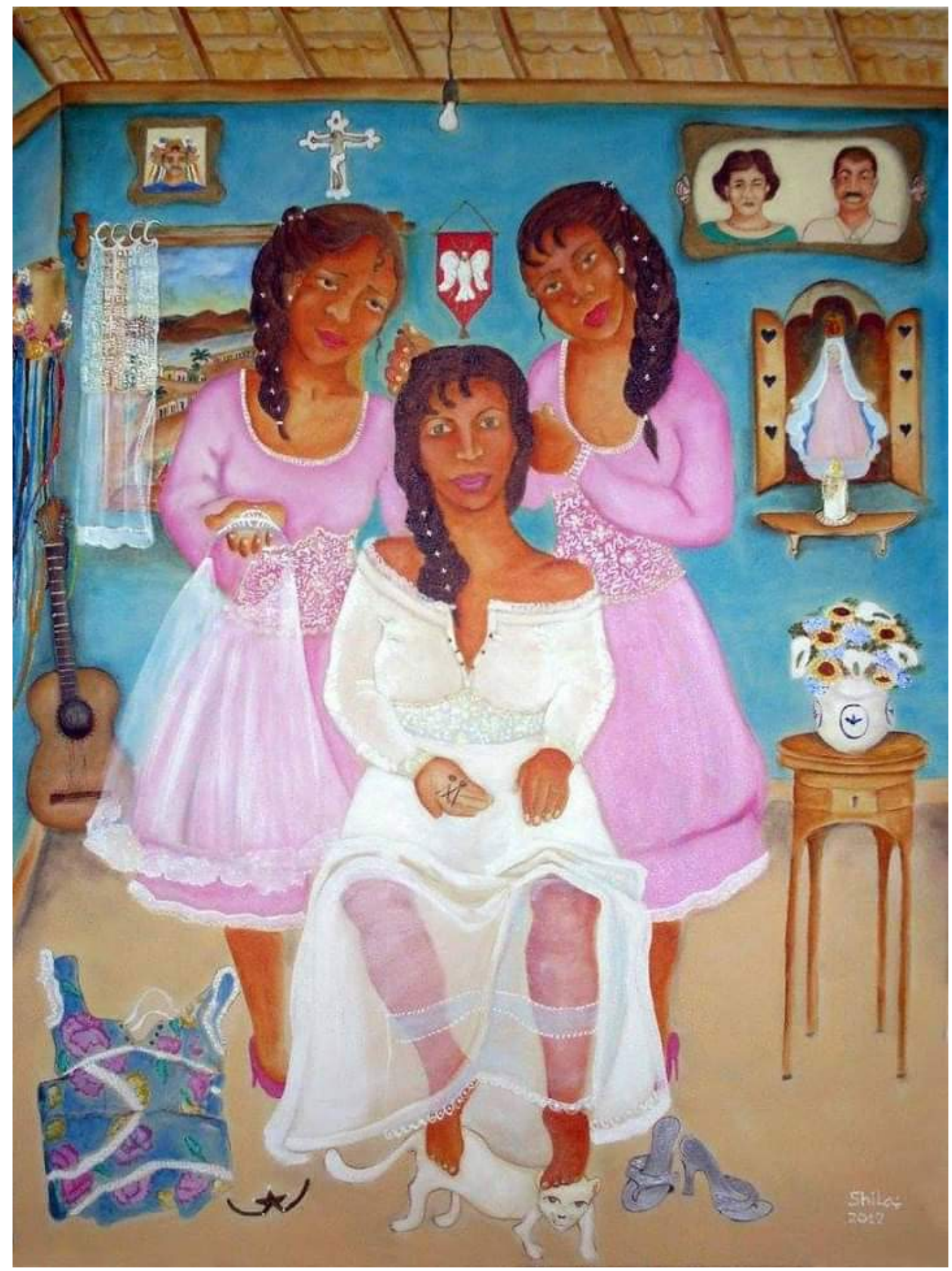

Fig. 02, O casamento da Pastorinha, 2012, acrílica sobre tela, 80×60 cm, coleção particular de Giovanni Cellamare. 


\section{O casamento}

O quadro conta a história de uma pastorinha no dia do casamento. A figura central está ladeada por duas moças mais jovens, que lhe arrumam os cabelos. As moças se vestem iguais, são damas de honra. Um gato afetivo se embala aos pés da figura central. O cenário insinua religiosidade, um violão encostado no canto, uma fotografia de homem... Talvez um irmão que era marujo de Reis, mas que partiu deixando muda sua viola. Há um oratório, uma fotopintura que viria a ser recorrente, flores num jarro de porcelana branca. Velaturas, narrativa e, por fim, o vestido de pastorinha abandonado no chão... Um rito de passagem ou dois? Narrativa, cor, técnica, emoção. Esses foram os elementos elencados.

Era como anotar os assuntos que precisavam ser falados numa conversa. Uma conversa pintada. Assim faço até hoje. Preciso saber o que quero dizer, escolher os elementos, relacioná-los, produzir símbolos e depois, através da relação, administrar os espaços. São as relações que administram qualquer espaço. Guardo isso para mim.

A partir daí, as cenas acontecidas no interior dos lares ocuparam meus pensamentos. Um lar pode ambientar-se de inúmeras maneiras. Um lar dá conforto para as pessoas serem o que realmente são, no que é bom e no que é ruim.

Na trilogia Interiores: A Novena, O Sono e a Benzedeira, as relações que tanto gosto ficam mais claras para mim. Aparentemente é uma cena só, mas tento construir micro-cenas que se integram. Os personagens têm interesses que diferem e suas individualidades estão em tempos diferentes. 


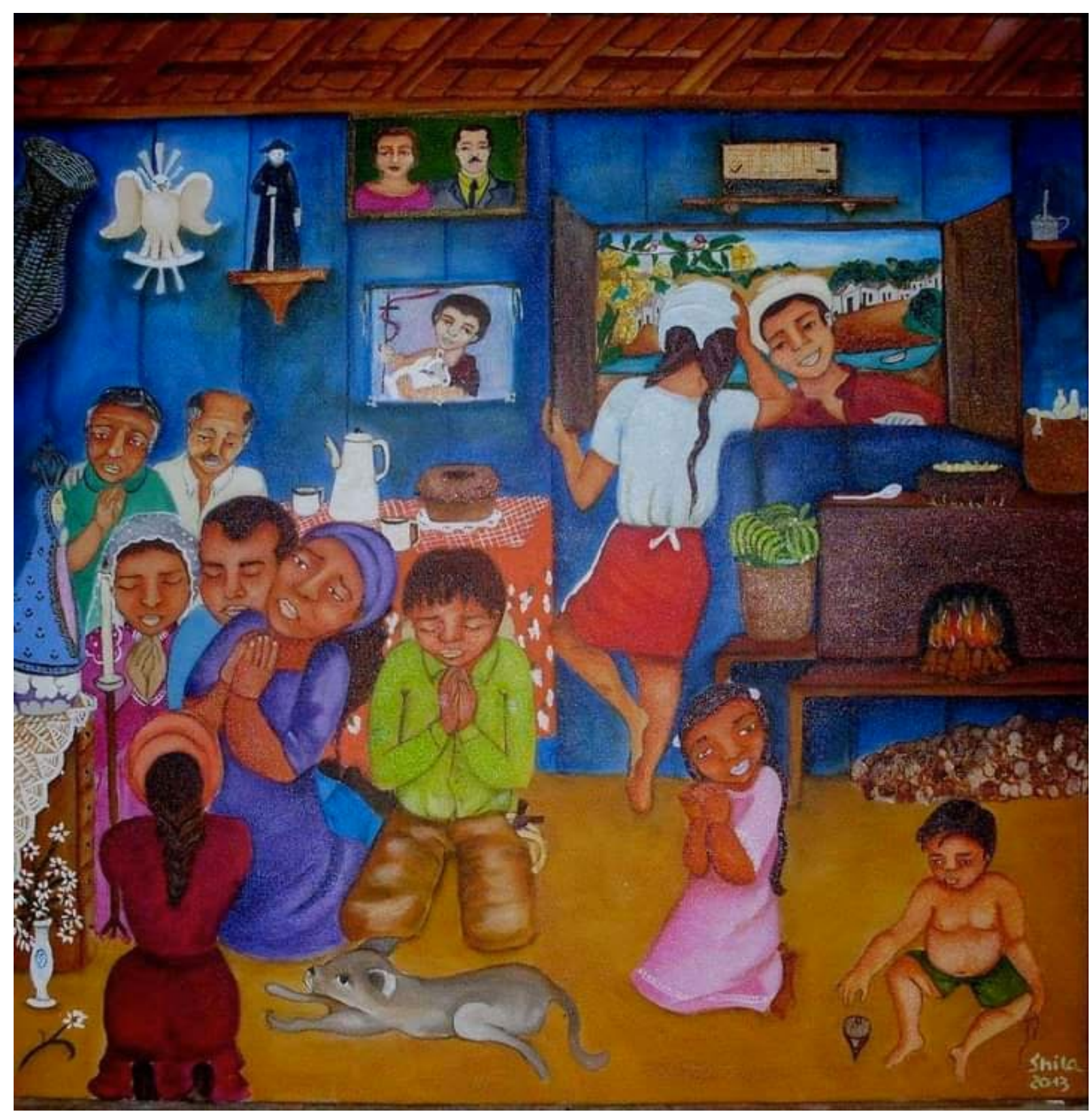

Fig. 03, A novena, 2013, acrílica sobre tela, 50×50cm, coleção Antônio Nascimento. 


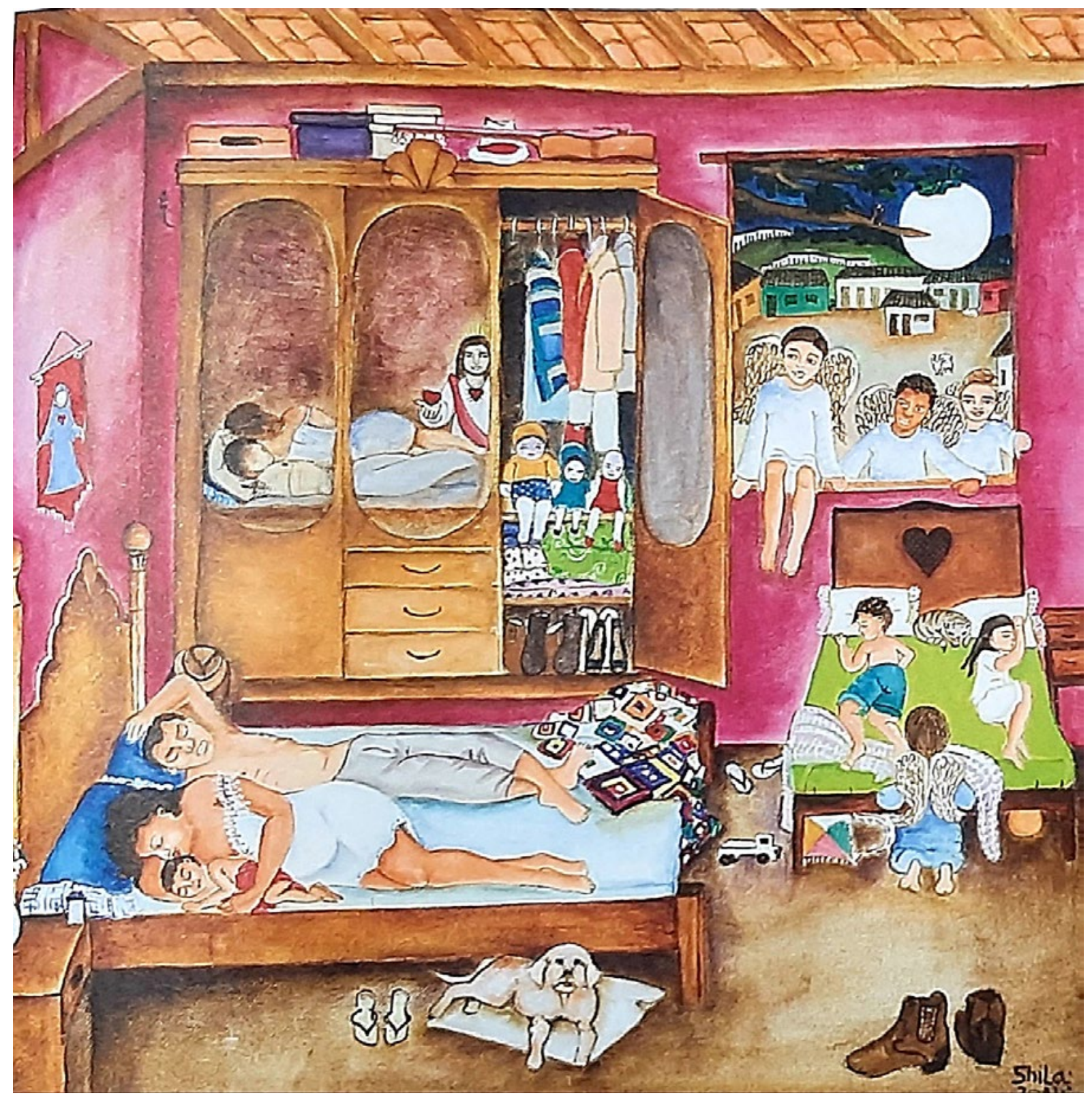

Fig. 04, O sono, 2013, acrílica sobre tela, 50×50 cm, coleção Giovanni Cellamare. 


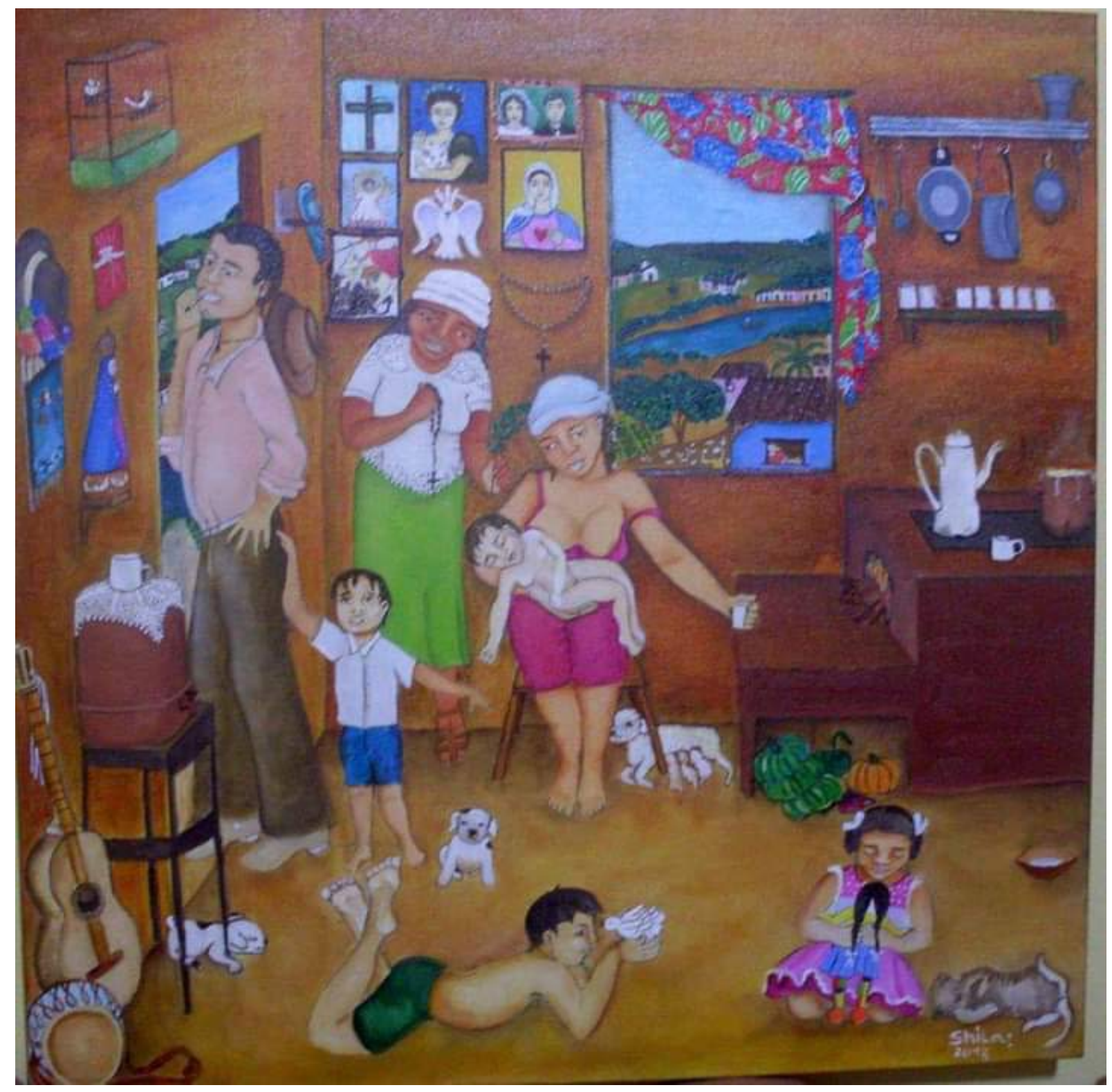

Fig. 05, A Benzedeira, 2013, acrílica sobre tela, 50×50, coleção Carlos Castro.

\section{Interiores}

O ambiente descreve as pessoas, o samburá na parede e o rio na paisagem da janela insinuam a pesca. A janela vai se repetir, a janela é a possibilidade, é o mundo de fora no mundo de dentro. Mas será a devoção à Maria (presença do sagrado) que integrará a solidão do velho à esquerda, o flerte dos jovens na janela, a comida se fazendo sozinha no fogão à lenha, o alheamento das crianças e dos bichos domésticos, que pouco compreendem o que acontece. A fotopintura dos antepassados fixadas na parede da sala tenta garantir que tudo seja como tem que ser. No Sono tem as cenas do espelho, os casais que dormem com tarefas diferentes: Ela, 
mãe e grávida, dormindo - assim mesmo, cuida do filho. $O$ homem, bem à vontade, apenas descansa. As crianças dormem cuidadas pelo gato e pelo sagrado. Só o cão sabe da visita noturna e parece olhar para o espectador, mas mira a figura denunciada no espelho. O sagrado no quadro A Benzedeira apoia-se nela própria e nas figuras da parede; junto à mãe e à criança, criam a cena principal. As duas compartilham a mesma realidade, a cachorrinha embaixo cuida de suas crias tal qual a mulher. Tudo é tão importante! Há um homem ausente perdido em seus pensamentos, as crianças devaneiam em seus mundos, há a família dos bichos existindo paralela a existência daquela família humana. O menino, perto do homem, aponta algo que o homem adulto não consegue ver. A natureza humana tão próxima das outras naturezas. $\bigcirc$ amor equivale tudo.

Na figura da Benzedeira, que será recorrente, exercito a crença no poder do sagrado feminino. A mulher que cura, dá vida e reflete a criação do mundo numa dinâmica de movimentos sem fim, que envolve tudo quanto tem vida, no céu e na terra. O poder criador que manipula todos os elementos, sobrevivendo à dor dessa criação infinita e caótica, espelhando o planeta. Gaia.

Ancoro nesse universo feminino e esboço o Ciclo da dor com os trabalhos Os Saqueadores e Bananeira que já deu cacho. Nas duas telas, a figura central são mulheres com o peito aberto. Há tantos buracos e frestas, por onde nós mulheres interagimos com o mundo, que os saqueadores sem rosto nascem desse pensamento. A tela denuncia indivíduos que se aproveitam do que há em nós, de mais belo, sem dar nada em troca e, por vezes, continuamos a dar, porque temos muito. As duas telas dizem das lágrimas femininas que se confundem com o suor, são formas irmãs, difícil saber qual é uma ou outra. Uma figura que dá infinitamente, e outra que não tem direito a envelhecer. A dor permeando a existência humana. 


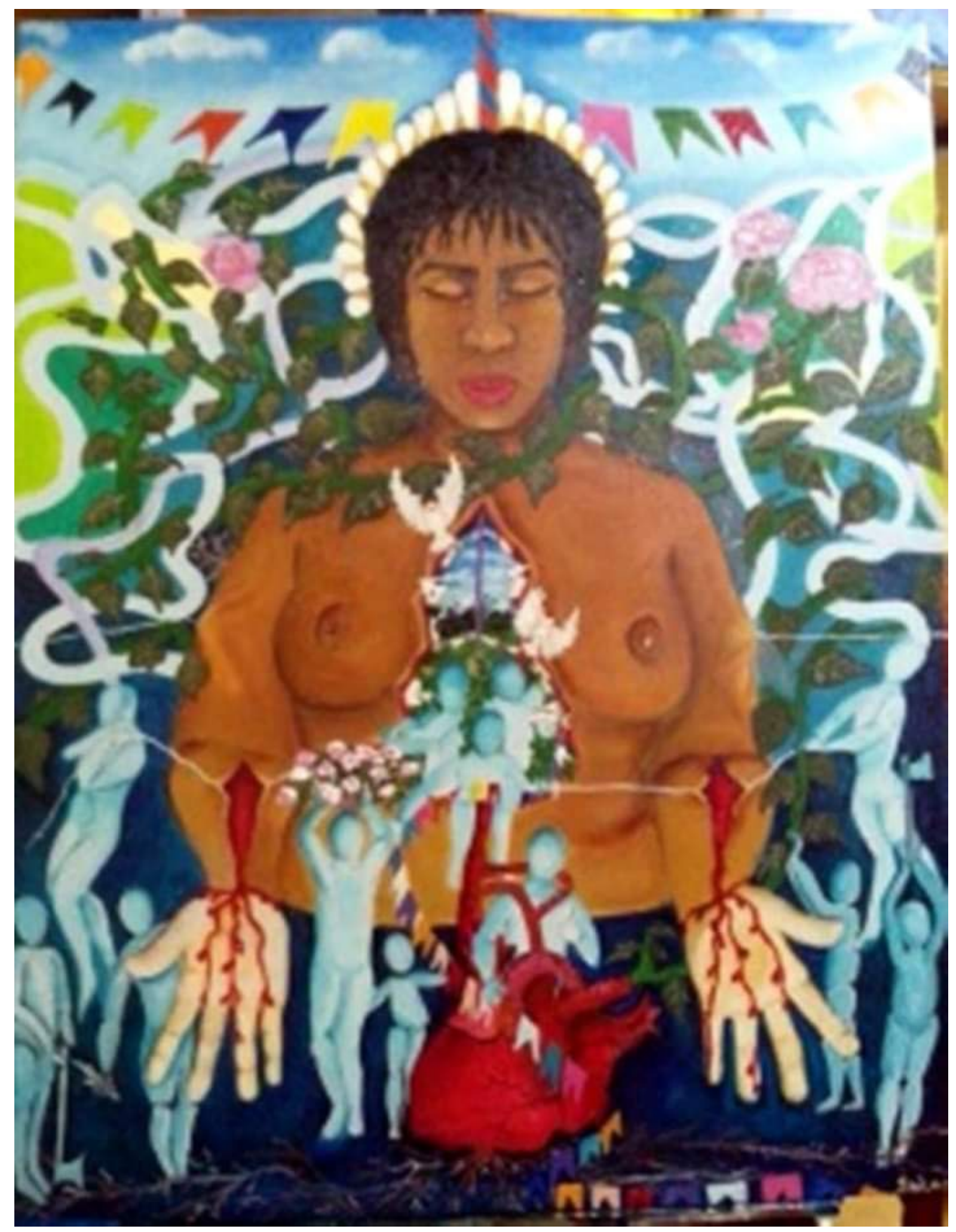

Fig. 06, Os Saqueadores, ano, acrílica sobre tela, 90x70, coleção Carla Magnhol. 


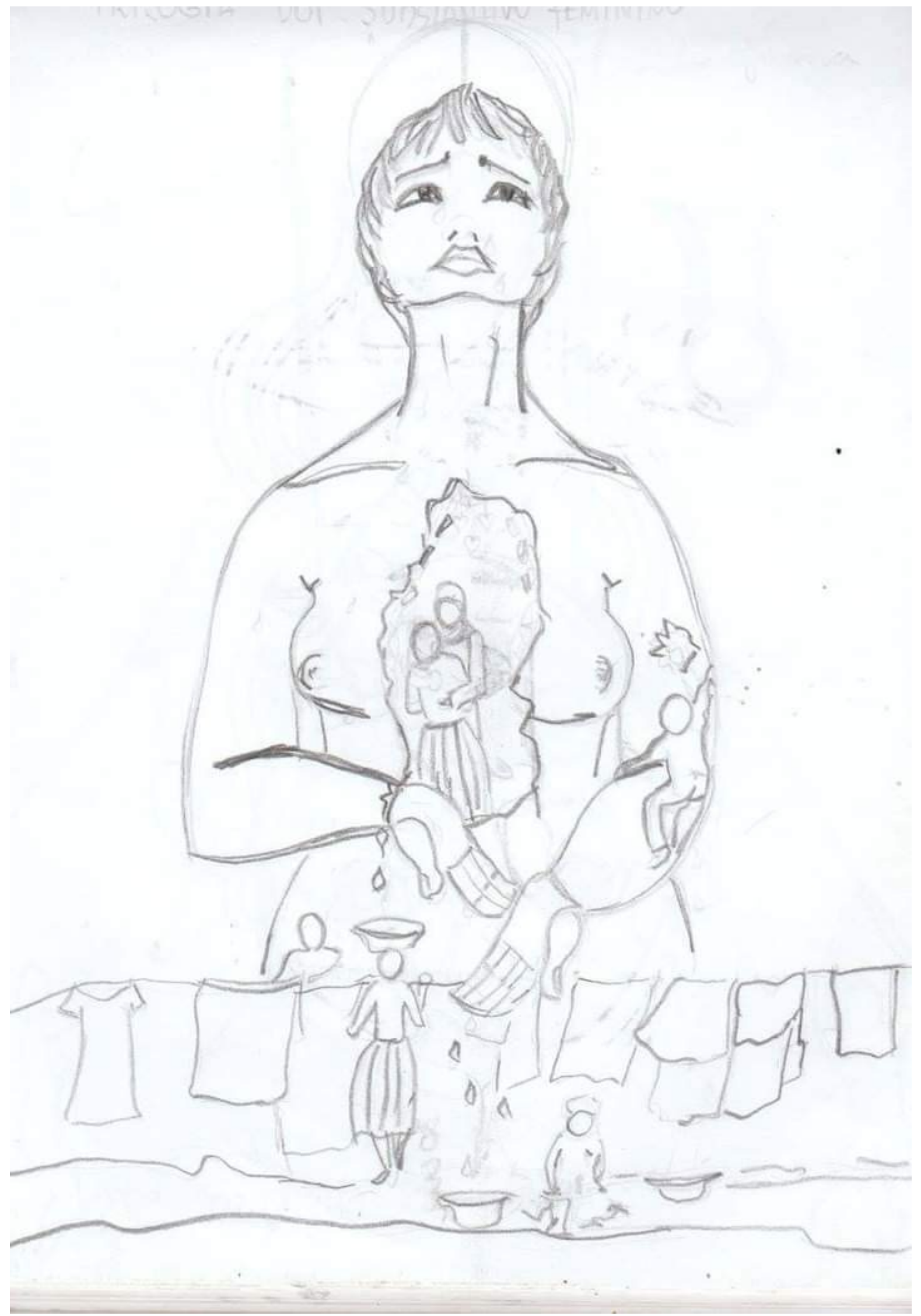

Fig. 07, Estudo para A Bananeira já deu cacho, 2018, grafite sobre papel, 29,7×21cm coleção da artista. 


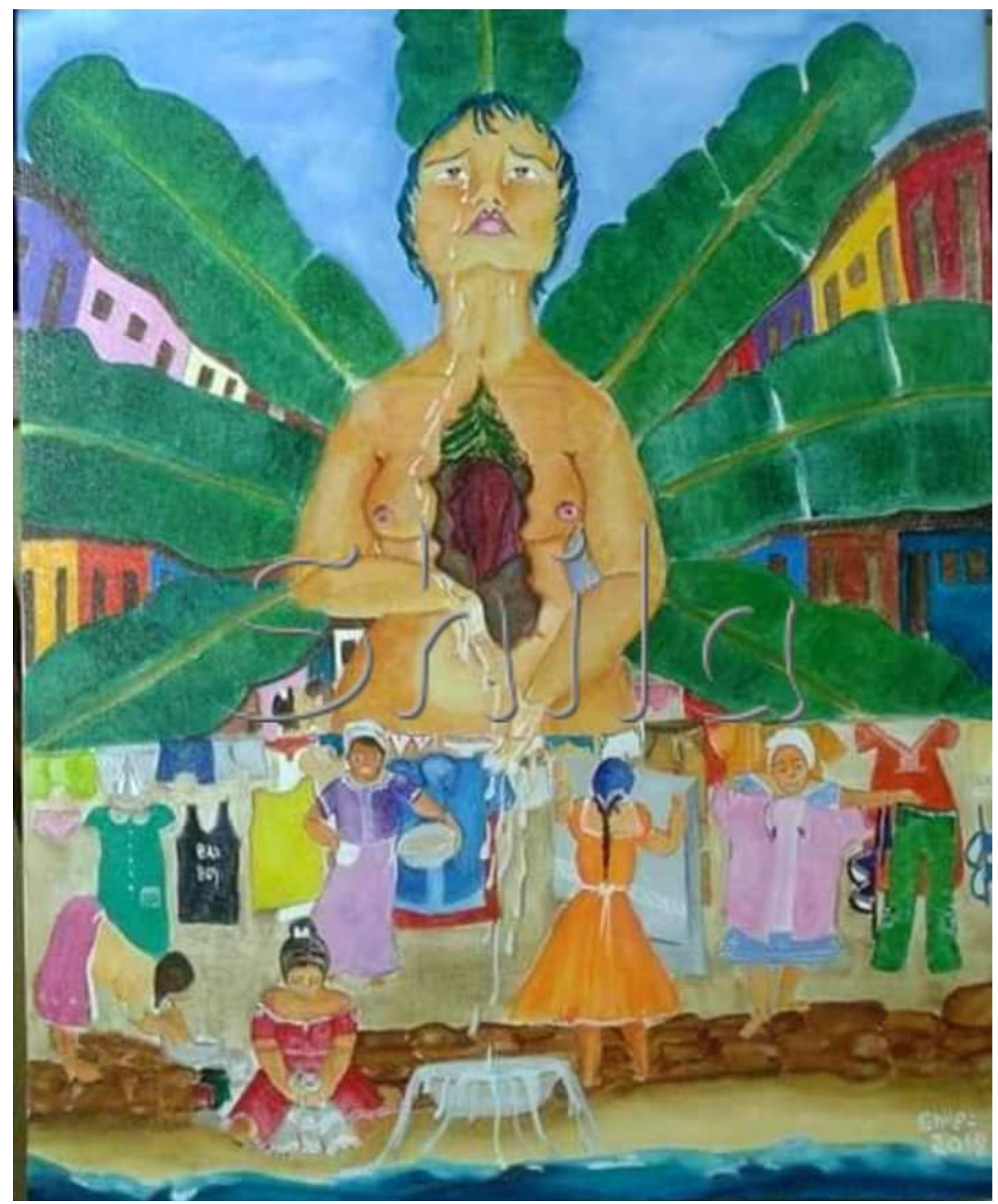

Fig. 08, A Bananeira já deu cacho, 2018, acrílica sobre tela, 50×40cm, coleção da artista.

Pintar é um pensar constante, num momento tem a beleza de elaborar volume e sombras com o "alisarim", e no outro há dor, há revolta, há afeto. Essas emoções são sentidas, são pensadas e evoluem no decorrer do trabalho. Quando acaba o processo, fica uma vontade do trabalho ir embora, andando sozinho. Porque tudo que tinha de acontecer, aconteceu no processo.

As Ciências Naturais da graduação em Educação do Campo aproximaram-me ainda mais da natureza e das questões ligadas à terra. Sou do interior do estado de 
São Paulo, de uma terra de monocultura. Cafezais e cana de açúcar fazem parte da paisagem e da história de onde nasci. Nunca senti desejo de pintar um canavial e, depois de compreender a sandice das monoculturas, quis menos ainda. Até porque, texturas e padronagens, por elas mesmas, nunca me interessaram.

O Martírio de Nossa Senhora do Brasil nasce desse contexto, mas nasce também de uma raiva fina, ácida e miúda. Uma raiva que vem de um conhecer a realidade e de uma impotência perigosa. Os elementos escolhidos por esses sentimentos que me moveram tinham a morte como elemento de intersecção. A morte da floresta, a morte nos e dos alimentos, a morte lírica de uma índia linda, imaginada num tempo distante e, não menos equivocado, por Victor Meirelles, minha própria ascendência indígena, a realidade cruel do país que agora, assolado pela ignorância e bestialidade, propõe a morte de tudo que quer Vida.

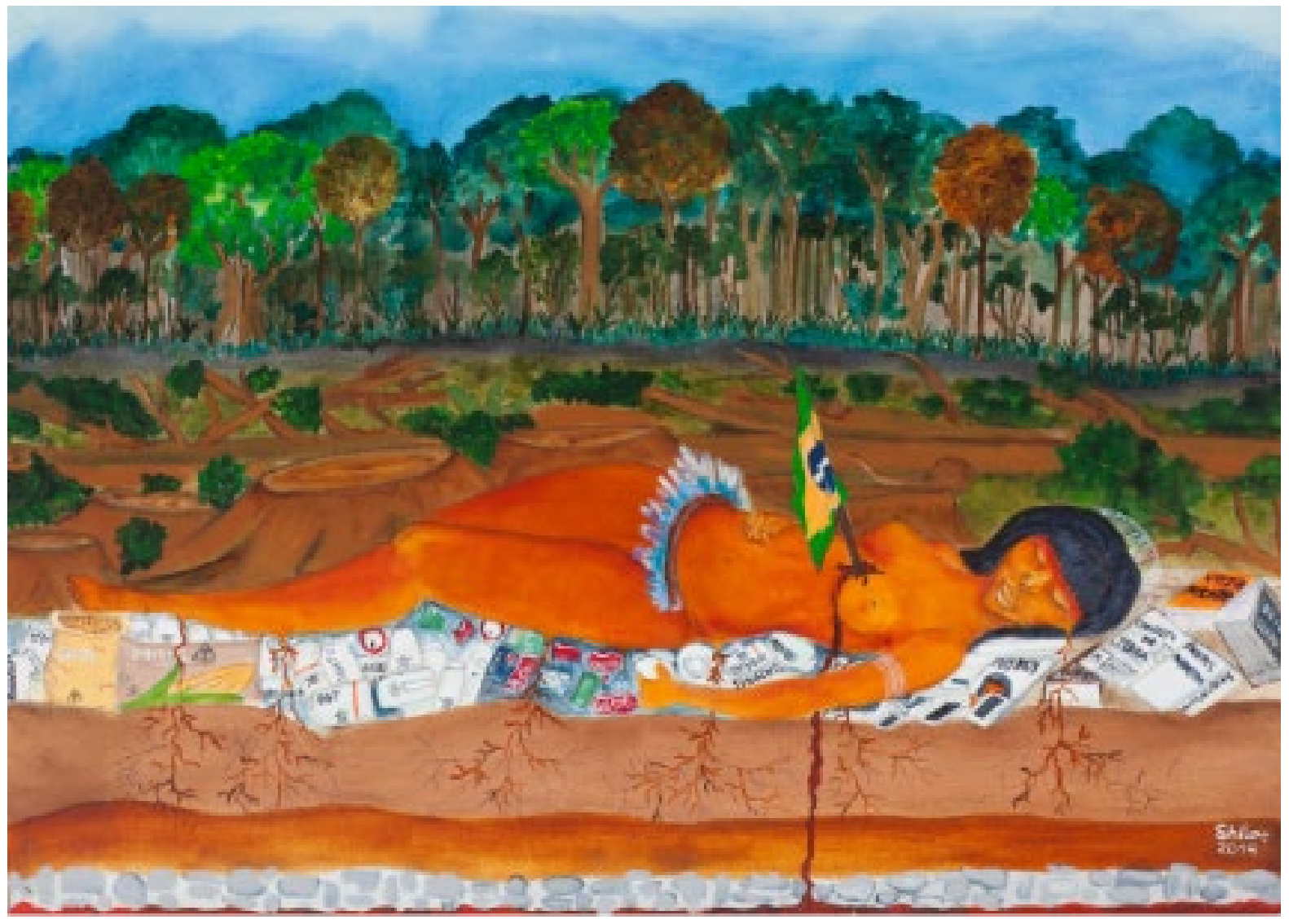

Fig. 09, O martírio de Nossa senhora do Brasil, 2019, acrílica sobre tela, 50x70cm, coleção SESC São Paulo.

A figura que corta a cena, e cujo peito é dilacerado por uma bandeirinha do Brasil, jaz num solo lixo, fruto da sociedade, dos poderes e da mídia lixo. Com isso, declarava morta e inútil qualquer tentativa de romantizar. Entendo que o quadro explica a nossa competência na implementação da morte. Somos bons em matar, mas o quadro propõe a resistência, o corpo enraíza, e seu sangue se mistura novamente à terra, o sangue é o sal da terra, porque tenho esperança de brotar. 